\title{
EDITORIAL
}

\section{Preventing disease in the twenty-first century: "Life is short, the Art long, opportunity fleeting..."}

\author{
Pediatric Research (2020) 87:181-182; \\ https://doi.org/10.1038/s41390-019-0655-6
}

The adage by Hippocrates (Fig. 1), better known by its Latin translation of the original Greek (vita brevis, ars longa, occasio praeceps), is an apt one for preventing disease. We have access to tremendous amounts of data, whose mining can inform us on all states of health and illness; technology has progressed to previously unsuspected heights in battling disease, building on past successes; and, scientific knowledge is advancing by the minute, allowing us to understand the structure of molecules, while elucidating complex interactions in cell-to-cell communication to systems biology at the organismal level.

Yet, the task of preventing disease is enormous on an earth that is projected to support 9.7 billion people by 2050 . $^{1}$ Preventing disease in the twenty-first century will rely on our ability to use technology to our advantage in developing disease preventative strategies over the decades ahead. The concurrent application of information technology, the accumulation and analysis of data, the development of new tools and molecular approaches in medicine, and the convergence of medical research support and health care delivery offer unique opportunities for disease prevention. If this opportunity is captured, disease prevention will lead us to not only living long and healthy lives, but also living

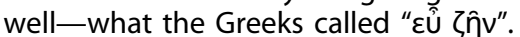

The importance of preventing disease was recognized early in the history of medicine. Hippocrates wrote that it is necessary to foretell disease if one wants to succeed in battling it; "it is usually too late, after you diagnose it". ${ }^{2}$ Huang Ti (2697-2597 BC) said that "the superior physician helps before the early budding of disease"; and, in the early days of modern medicine, William J. Mayo said that "the aim of medicine is to prevent disease and prolong life; the ideal of medicine is to eliminate the need of a physician". ${ }^{3}$

Approaches to disease prevention, too, started early in human history. There are many examples of efforts to prevent disease in pre-historic times, such as the advent of sewage drainage and quarantining individuals with infections to prevent the spread of communicable diseases. As early as between 120 and 60 BCE, King Mithridates of Pontus exposed himself to poison, snake-derived and other toxins, to prevent his death from one of these substances by building innate defenses against them. The concept of building innate immunity by vaccination was popularized by Edward Jenner in the late 1700 s to protect against smallpox. ${ }^{4}$

Today, we understand prevention to be an important pillar of modern health care. ${ }^{5}$ We now recognize that disease prevention begins before conception, as the developmental origin of health and human disease (DOHaD) theory proposes. ${ }^{5-7}$ There are plenty of data that support the need for diverse forms of early interventions in many aspects of medicine. ${ }^{8}$ Exposures to emotional stressors, or other stress, during childhood is associated with increased morbidity during adulthood. ${ }^{9,10}$ A variety of social and medical factors are associated with preterm birth, which is associated with metabolic disturbances in later life. ${ }^{9,11}$ Long-term

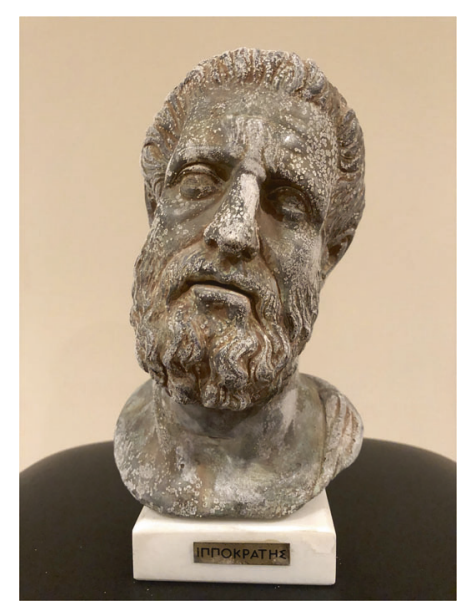

Fig. 1 Hippocrates: the writer of the Hippocratic oath and the first textbooks of medicine. This bust is a replica of Hippocrates' head from an original statue that was found near the Odeon on the Island of Kos. Second century BCE Athens, Archaeological Museum

exposures to environmental toxins may be associated with certain forms of cancer. ${ }^{12,13}$ The metabolic state and diets of parents can influence the risk of obesity for their children and grandchildren. ${ }^{14,15}$

Beyond DOHaD, prevention is essential for other aspects of care that influence health and disease. ${ }^{16-19}$ Today's globalization requires actions that are internationally coordinated. ${ }^{20,21}$ The World Health Organization (WHO) recommends interventions to promote optimal child survival, growth, and development, which include medical system organization and vaccination strategies. ${ }^{22}$ However, further efforts and research are needed in applying these measures to diverse populations, particularly in low-resource settings. ${ }^{20}$

Excellent examples of global coordination in preventative health care are seen in recent responses to potential serious new pandemics, that include Ebola and Zika. ${ }^{23}$ The preventable measles outbreaks seen in many regions of the world also show what can go awry when proven and effective vaccine-based disease prevention measures are not universally applied. ${ }^{24}$ Preventing the consequences of the next epidemic of a communicable disease is an obligation for the twenty-first century. It is said that "if you can predict it, you can prevent it." From the infamous Black Death that devastated the newly established urban centers of Europe $(1346-1353 \mathrm{CE})^{25}$ to the recent spread of Ebola in rapidly urbanizing sub-Saharan Africa, ${ }^{26}$ the consequences of serious infections can be predicted from their biology. Our knowledge of human immunodeficiency virus (HIV) is now to the point where we can discuss ways to "end the HIV epidemic," showing how preventive measures coupled with pharmacological interventions can be effective. ${ }^{27}$

Advances in neurosciences, structural system, and cell biology, along with the sequencing of the genomes of living organisms, are essential tools in preserving health and fighting disease. These advances have resulted in reduced mortality for certain types of 
cancer, ${ }^{13}$ for example. Genetic sequencing informs about the predisposition to a number of conditions, susceptibility to infectious agents, responses to the environment, and so many other aspects of life and disease. Genomics is now a major part of what we call precision medicine, a true revolution, as indeed had been promised the then newly appointed head of the National Institutes of Health (NIH), Francis Collins. ${ }^{28}$

This issue of Pediatric Research dedicated to prevention is a wonderful collection of reports that capture the challenges of preventing disease in the twenty-first century and the tremendous opportunities afforded to us by technology and other advances. This issue is especially timely as the Eunice Kennedy Shriver National Institute of Child Health \& Human development (NICHD) recently released its strategic plan for the next 5 years $(2020-2024) .^{29}$ A key element of NICHD's vision is prevention: "healthy pregnancies, healthy children, healthy and optimal lives." The current special issue of Pediatric Research touches on many subjects including, preventing long-term effects of stress, cardiovascular disease and injuries, the value of immunizations, and the fight against infectious agents. Articles highlight the emerging role of genomics and precision medicine, advances in what affects the function and the immune system, and beyond. Indeed, this issue covers a wide range of issues reflecting the entire spectrum of pediatrics.

As momentous as the task of preventing disease is, the opportunity should not be wasted: technological advances, massive information, huge databases and new analytical tools, artificial intelligence, and the understanding of molecular basis of everything from genetics to the various omics (transcriptomics and proteomics, methylome, and the microbiome) allow us to dream that William J. Mayo's ideal of "medicine without physicians" is a reachable feat and that the humans of the future will not only live long and healthy lives but live well, as Hippocrates would have wanted them to.

\section{ACKNOWLEDGEMENTS}

We thank Dr. Vesna Kutlesic, Director of the Office of Global Health (OGH) of the Eunice Kennedy Shriver National Institute of Child Health \& Human development (NICHD), Bethesda, MD; Dr. Kutlesic provided information and material on NICHD's efforts on preventing disease from the global health perspective. Lastly, we thank Dr. Diana Bianchi, Director, NICHD for her support and leadership. This work was supported by the Intramural Research Program of the Eunice Kennedy Shriver National Institute of Child Health \& Human Development (NICHD).

\section{ADDITIONAL INFORMATION}

Competing interests: Dr. Stratakis' laboratory has research funding from Pfizer, Inc., and holds patents on cyclic AMP signaling genes and related issues.

Publisher's note Springer Nature remains neutral with regard to jurisdictional claims in published maps and institutional affiliations.

Constantine A. Stratakis ${ }^{1,2}$ and Scott A. Rivkees ${ }^{1,3}$ ${ }^{1}$ Eunice Kennedy Shriver National Institute of Child Health \& Human Development (NICHD), NIH, Bethesda, MD, USA; ${ }^{2}$ Section on

Endocrinology and Genetics (SEGEN), NICHD, NIH, Bethesda, MD, USA and ${ }^{3}$ Department of Pediatrics, University of Florida, Gainesville, $F L$ 32610, USA

These authors contributed equally: Constantine A. Stratakis, Scott A. Rivkees

Correspondence: Constantine A. Stratakis (stratakc@mail.nih.gov)

\section{REFERENCES}

1. Office of the Director, Population Division, United Nations. https://population.un. org/wpp/Publications/Files/WPP2019_Highlights.pdf. Accessed 13 Oct 2019.

2. Hippocrates. Prorrhetic II. HIPPOCRATES, VOLUME VIII, Edited and translated by Paul Potter (Harvard Univ. Press, Cambridge, MA, 1995).

3. University of Cambridge, School of Clinical Medicine, Department of Public Health and Primary Care. https://www.phpc.cam.ac.uk/files/2014/03/ PublicHealthEducation.pdf. Accessed 13 Oct 2019.

4. Zerhouni, E. GAVI, the vaccine alliance. Cell 179, 13-17 (2019).

5. Fani Marvasti, F. \& Stafford, R. S. From "Sick Care" to health care: reengineering prevention into the U.S. system. N. Engl. J. Med. 367, 889-891 (2012).

6. Barker, D. J. The fetal origins of adult disease. Fetal Matern. Med. Rev. 6, 71-80 (1994).

7. Penkler, M., Hanson, M., Biesma, R. \& Müller, R. DOHaD in science and society: emergent opportunities and novel responsibilities. J. Dev. Orig. Health Dis. 10, 268-273 (2019).

8. Schor, E. L. American Academy of Pediatrics task force on the family. Family pediatrics: report of the task force on the family. Pediatrics 111(Part 2), 1541-1571 (2003).

9. Fleiss, B., Rivkees, S. A. \& Gressens, P. Early origins of neuropsychiatric disorders. Pediatr. Res. 85, 113-114 (2019).

10. Murphy, M. L. M., Cohen, S., Janicki-Deverts, D. \& Doyle, W. J. Offspring of parents who were separated and not speaking to one another have reduced resistance to the common cold as adults. Proc. Natl Acad. Sci. USA 114, 6515-6520 (2017).

11. Moster, D., Lie, R. T. \& Markestad, T. Long-term medical and social consequences of preterm birth. N. Engl. J. Med. 359, 262-273 (2008).

12. World Cancer Research Fund International. Diet, Nutrition, Physical Activity and Cancer: A Global Perspective; The Third Expert Report. https://www.wcrf.org/ dietandcancer. Accessed 14 Oct 2019.

13. Welch, H. G., Kramer, B. S. \& Black, W. C. Epidemiologic signatures in cancer. N. Engl. J. Med. 381, 1378-1386 (2019).

14. Elshenawy, S. \& Simmons, R. Maternal obesity and prenatal programming. Mol. Cell Endocrinol. 435, 2-6 (2016).

15. Houfflyn, S., Matthys, C. \& Soubry, A. Male obesity: epigenetic origin and effects in sperm and offspring. Curr. Mol. Biol. Rep. 3, 288-296 (2017).

16. Velazquez, M. A., Fleming, T. P. \& Watkins, A. J. Periconceptional environment and the developmental origins of disease. J. Endocrinol. 242, T33-T49 (2019).

17. Ferraz, M. A. M. M. et al. An oviduct-on-a-chip provides an enhanced in vitro environment for zygote genome reprogramming. Nat. Commun. 9, 4934 (2018).

18. Jain, T. et al. 30 years of data: impact of the United States in vitro fertilization data registry on advancing fertility care. Fertil. Steril. 111, 477-488 (2019).

19. Verhulst, A., Beltran-Sanchez, H. \& Palloni, A. Impact of delayed effects on human old-age mortality. Demogr. Res. 40, 1167-1210 (2019).

20. Kutlesic, V., Brewinski Isaacs, M., Freund, L. S., Hazra, R. \& Raiten, D. J. Executive summary: research gaps at the intersection of pediatric neurodevelopment, nutrition, and inflammation in low-resource settings. Pediatrics 139(Suppl. 1), S1-S11 (2017).

21. Chan, M. Linking child survival and child development for health, equity, and sustainable development. Lancet 381, 1514-1515 (2013).

22. World Health organization (WHO). Maternal, Newborn, Child \& Adolescent Health Department. https://www.who.int/pmnch/topics/part_publications/ essential_interventions_18_01_2012.pdf.

23. Musso, D., Ko, A. \& Baud, D. Zika virus infection-after the pandemic. N. Engl. J. Med. 381, 1444-1457 (2019).

24. Paules, C. I., Marston, H. D. \& Fauci, A. S. Measles in 2019-going backward. N. Engl. J. Med. 380, 2185-2187 (2019).

25. Spyrou, M. A. et al. Phylogeography of the second plague pandemic revealed through analysis of historical Yersinia pestis genomes. Nat. Commun. 10, 4470 (2019).

26. Gostin, L. et al. Ebola in the Democratic Republic of the Congo: time to sound a global alert? Lancet 393, 617-620 (2019).

27. Fauci, A. S., Redfield, R. R., Sigounas, G., Weahkee, M. D. \& Giroir, B. P. Ending the HIV epidemic: a plan for the United States. JAMA 321, 844-845 (2019).

28. Collins, F. Has the revolution arrived? Nature 464, 674-675 (2010).

29. Eunice Kennedy Shriver National Institute of Child Health \& Human Development (NICHD). https://www.nichd.nih.gov/about/org/strategicplan. Accessed 14 Oct 2019. 